\title{
急性副鼻腔炎治療における耳鼻科的処置の有用性
}

\author{
横浜労災病院耳鼻咽喉科 \\ 高野 信也, 川俣光, \\ 佐久間 貴章, 山田尚宏
}

\section{Utility of Otolaryngological Approaches for the Treatment of Acute Sinusitis}

\author{
Shinya Takano, Teru Kawamata, Takaaki Sakuma, \\ Naohiro Yamada \\ Department of Otorhinolaryngology, Yokohama Rosai Hospital, Yokohama
}

We examined the influence of otolaryngological treatments, such as the expiratory puncture and irrigation of the maxillary sinus by needle (Schmidt method), nebulizer and the Proetz method, on the treatment period of acute sinusitis.

The subjects were 189 patients with unilateral acute sinusitis, who were treated at Yokohama Rosai Hospital from January 2001 to December 2003.

The point at which a cure was achieved was defined as the day when symptoms resolved and the nasal findings and $\mathrm{X}$-ray findings, and the treatment period was defined as the interval between the first examination and the resolution of the disease.

The following factors were investigated: (1) age $(<20$ years old, twenties, thirties, forties, fifties, sixties, and $\geqq 70$ years old) ; (2) duration of illness (3 days or less, 5 days or less, 7 days or less, 10 days or less, 14 days or less, 30 days or less, and 70 days or less) ; (3) the presence of concomitant allergic rhinitis $(+$ or - ) ; and (4) otolaryngological treatments (nebulizer, Proetz method, Schmidt method, or no procedure ; (5) antibiotics (macrolides, penicillin, new quinolone, cephems, or no antibiotics). The influence of these factors on the treatment period was investigated by multivariate analysis using Stat Partner for Windows Ver. 4 . 5 (NEC Software Company).

The factors that showed a significant influence on the treatment period were age, antibiotics, otolaryngological treatment and the duration of the illness.

The Proetz method and use of a nebulizer extended the treatment period in patients less than 20 years old and patients in their sixties. On the other hand, the Schmidt method extended the treatment period as the duration of the illness was extended.

From these data, we considered that the Schmidt method was useful in the younger patient population.

Key words：急性副鼻腔炎, 上顎洞穿刺洗浄法, Proetz 氏置換法，ネブライザー 


\section{I . はじめに}

日本における急性副鼻腔炎の治療法には, 上顎洞穿刺 洗浄法 (以下 Schmidt と略す), ネブライザー療法 (以 下 Neb と略す), Proetz 氏置換法 (以下 Proetz と略す) および YAMIK 法の耳鼻科的処置と抗生剂等の内服薬治 療がある。そして, 本邦においては, Nebおよび抗生 剤投与で治療を行うことが多い。

以前に, 急性副鼻腔炎症例215例について検討し, 治 療期間に及ほす因子について多変量解析を用いて分析 し, 䍜患期間, アレルギー性鼻炎の合併の有無, 年齢層, および耳鼻科的処置の順に大きく寄与していることを報 告した1”。しかし, 実際の日常診療においては, 䍜患期 間等を考慮して治療法を選択している訳ではない。診療 を担当する耳鼻科専門医の診療経験をもとに治療法を選 択しているのが実際である。また, 内服抗生剤の種類に ついても欧米のガイドラインに準じて選択していること も多い。本邦における急性副鼻腔炎は, 検出される菌種 も欧米と異なり, 本邦独自の治療ガイドラインの作成が 必要と考える。また, これに準じて最良の治療を行うこ とは，医療経済的にも重要であると考える。

\section{II. 研究対象および研究方法}

研究対象は, 2001年 1 月から 2003年12月までに横浜労 災病院耳鼻咽喉科において初期から治療を行うことがで きた一側性急性副鼻腔炎189例である。全症例に単純 X$\mathrm{P}$ 検査を施行し, 上顎洞および篩骨洞に中程度以上の陰 影を認めた。

男性104例および女性85例であった。Proetz 群が31 例，Neb 群が49例および Schmidt 群が109例であった。

耳鼻科的処置は来院順に Proetz 群, Neb 群, Schmidt 群の順に振り分けた。 5 日毎に耳鼻科的処置を行い, 治 癒日まで耳鼻科的処置を継続した。

症例の年齢分布を図 1 に示す。平均年齢は, Proetz 群で, 男性32.4歳, 女性28.2歳であった。

また, Neb 群で男性37.3歳, 女性41.2歳であった。 また, Schmidt 群で, 男性40.6歳, 女性34.8歳であった。

鼻症状が消失し, 単純 X-P 検査において陰影が消失 した日を治癒日とした。そして, 治癒日と初診日との期 間を治療期間と定義した。

治療期間を決定するのに寄与していると考えられる因 子を以下： 1)年齢 (<20歳, 20 歳代, 30 歳代, 40 歳代, 50 歳代，60歳代およびミ70歳)，(2)罹患期間 ( 3 日以下， 5 日以下，7 日以下，10日以下，14日以下，30日以下およ び70日以下), (3)アレルギー性鼻炎合併の有無（+又は
一)，および(4)内服抗生剂の種類（マクロライド（以下 $\mathrm{MC}$ と略す), ペニシリン (以下 Pc と略す), 合成抗菌 剂, セフェム系および抗生剤なし)の 5 つの因子とした。 治療期間の決定に，これら 5 つの因子がどのように寄与 するかを NECソフトウエア社製 Stat Partner for Windows Ver. 4. 5 を用いて分析した。分析は多変量解析を 行った。

\section{III. 多変量解析について}

多変量解析とは, 多量の変数（デー夕種類）を対象と して，その変量を集約しながら特徴把握やその他の分析 を行うための統計学的手法の総称である。

被説明変数 (外的基準) が量的データで, 説明変数が 質的データであるときに行う手法を数量化一類といい, 重回帰分析と同じ目的で行われる分析法である。今回， 我々は外的基準が治療期間で量的デー夕となり, 説明変 数が質的データであるために，この分析を行った。

\section{N. 結 果}

\section{1） Proetz 群について}

Proet $z$ 施行した 31 例についての分析結果を表 1 に 示す。重相関係数は, $r=0.6432$ で回帰式が成立した。 表 1 の範囲から，治療期間の決定には，年齢層が大きく 寄与していることがわかった。その関係を図 2 に示す。 Proetz 群では, 40歳代で治療期間が短く, 有用な治療 法である。しかし，20歳未満および60歳代では，治療期 間が25日前後で，有用な治療法とは言い難い。

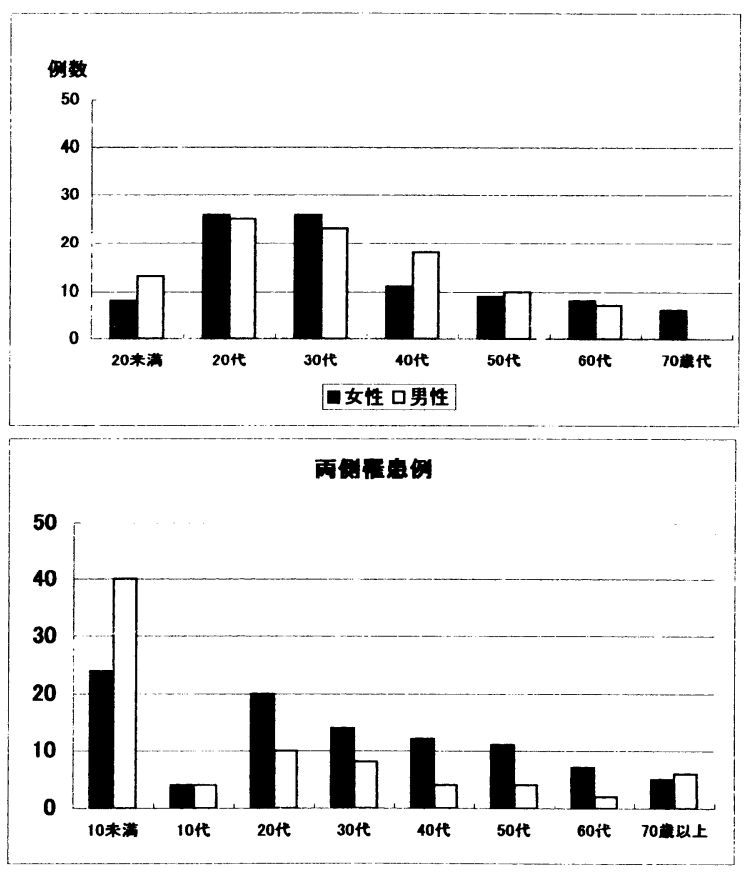

図 1 年齢分布 
表 1 多変量解析結果 (Proetz)

\begin{tabular}{|c|c|c|c|c|}
\hline & & カテゴリー数量 & 度数 & 範囲 \\
\hline \multirow[t]{6}{*}{ 年齢層 } & 20歳未満 & -10.46449 & 7 & 84.646 \\
\hline & 20 代 & -9.81939 & 8 & \\
\hline & 30 代 & -6.89843 & 9 & \\
\hline & 40代 & -5.03297 & 3 & \\
\hline & 50 代 & 6.36092 & 1 & \\
\hline & 60 代 & 74.21014 & 3 & \\
\hline \multirow[t]{7}{*}{ 罹患期間 } & 1 日以内 & 18.44184 & 6 & 45.676 \\
\hline & 3 日以内 & -9.52222 & 3 & 3 \\
\hline & 5 日以内 & -5.33176 & 3 & \\
\hline & 7 日以内 & -3.77882 & 7 & \\
\hline & 10日以内 & -27.23447 & 1 & \\
\hline & 14日以内 & -4.22956 & 6 & \\
\hline & 30日以内 & 2.59489 & 5 & \\
\hline \multirow[t]{3}{*}{ 抗生剂 } & セフェム & -12.15511 & 12 & 29.665 \\
\hline & マクロライド & 17.51049 & 10 & 6 \\
\hline & 抗生剂なし & -3.24929 & 9 & \\
\hline \multirow[t]{2}{*}{ アレルギー性鼻炎合併 } & $(+)$ & 17.25316 & 4 & 19.809 \\
\hline & $(-)$ & -2.55602 & 27 & 2 \\
\hline
\end{tabular}

\begin{tabular}{|c|c|}
\hline 重相関係数 & 決定係数 \\
\hline 0.6432 & 0.4137 \\
\hline
\end{tabular}

Proetz

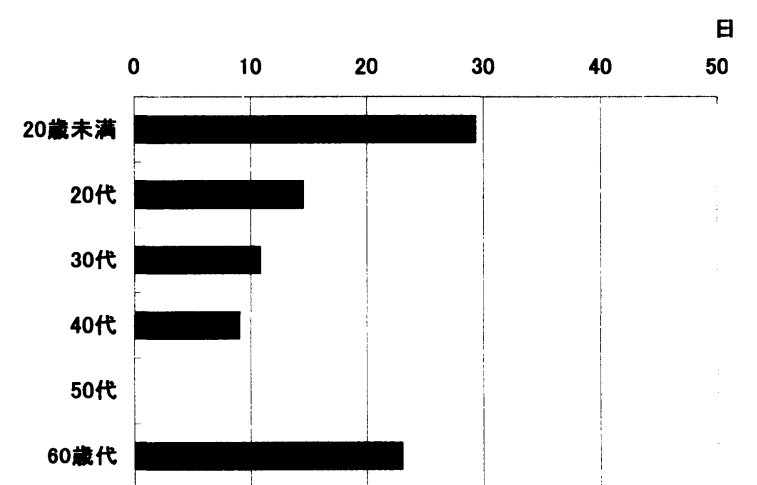

図 2 治療期間と年齢層の関係 (Proetz)

2) Neb 群について

Neb を施行した49例のついての分析結果を表 2 に示 す。重相関係数が $\mathrm{r}=0.6107$ で回帰式が成立した。表 2 の範囲から, 治療期間の決定には, 年齢層が大きく寄与 していることがわかった。その関係を図 3 に示す。Neb 群では，60歳代の症例で治療期間が 30.8 日で有用な治療 法では言い難い。

3) Schmidt 群について

Schmidt を施行した109例についての分析結果を表 3 に示す。重相関係数が $\mathrm{r}=0.5455$ で回帰式は成立した。 表 3 の範囲から, 治療期間の決定には, 罹患期間が大き
く寄与していることがわかった。その関係を図 4 に示 す。罹患期間が15日を越えると治療期間が長くなること がわかった。

\section{4）年齢層と耳鼻科的処置}

各年齢層別に各耳鼻科的処置の平均治療期間を図 5 に 示す。Proetzは20，30および40歳代で有用な治療法で ある。また, Neb は30, 40歳代で有用である。しかし, 20 歳未満では, Nebの方が有用である。

Schmidt は, 各年齢層で最も有用な治療法であるが, 60 歳代では他の年齢層の Proetz および Nebに比しても有 用とは言い難い。

\section{V. 考 察}

アメリカ合衆国においては，急性副鼻腔炎治療法にお ける抗生剤および耳鼻科的処置の選択法のガイドライン が存在する2)。しかし，日本においては，そのようなガ イドラインは存在しない。欧米で小児急性副鼻腔炎から 検出された最も高頻度な菌種はS. pneumoniae および M. catarrhalis, であり,これらに対する第一選択はア モキシリンである3)。しかし，日本における小児急性副 鼻腔炎から最も多く検出された菌種はS. pneumoniae お よびH. influenzaeであっだ)。山中も, PRSPおょび BLNARの検出率が高くなっており, Schmidtのような 
表 2 多変量解析結果 $(\mathrm{Neb})$

\begin{tabular}{|c|c|c|c|c|}
\hline & & カテゴリー数量 & 度数 & 範囲 \\
\hline \multirow[t]{7}{*}{ 年齢層 } & 20歳未満 & -10.22500 & 5 & 34.044 \\
\hline & 20 代 & 2.69234 & 10 & 7 \\
\hline & 30 代 & -7.20117 & 13 & \\
\hline & 40代 & -1.22928 & 8 & \\
\hline & 50 代 & -2.31520 & 6 & \\
\hline & 60 代 & 23.81970 & 6 & \\
\hline & 70歳代 & -1.37594 & 1 & \\
\hline \multirow[t]{7}{*}{ 罹患期間 } & 1 日以内 & -2.85585 & 3 & 30.752 \\
\hline & 3 日以内 & 6.47937 & 6 & 0 \\
\hline & 5 日以内 & -1.73552 & 3 & \\
\hline & 7 日以内 & -1.24259 & 14 & \\
\hline & 10日以内 & -24.27265 & 2 & \\
\hline & 14日以内 & 4.08674 & 9 & \\
\hline & 30日以内 & 0.33824 & 12 & \\
\hline \multirow[t]{2}{*}{ アレルギー性鼻炎合併 } & $(+)$ & 19.49615 & 7 & 22.745 \\
\hline & $(-)$ & -3.24936 & 42 & 5 \\
\hline \multirow[t]{5}{*}{ 抗生剤 } & セフェム & -2.43843 & 15 & 7.6692 \\
\hline & ペニシリン & 2.99924 & 1 & \\
\hline & マクロライド & 0.09913 & 10 & \\
\hline & 合成抗菌剤 & 5.23074 & 3 & \\
\hline & 抗生剤なし & 0.84469 & 20 & \\
\hline
\end{tabular}

\begin{tabular}{|c|c|}
\hline 重相関係数 & 決定係数 \\
\hline 0.6107 & 0.3729 \\
\hline
\end{tabular}

Neb

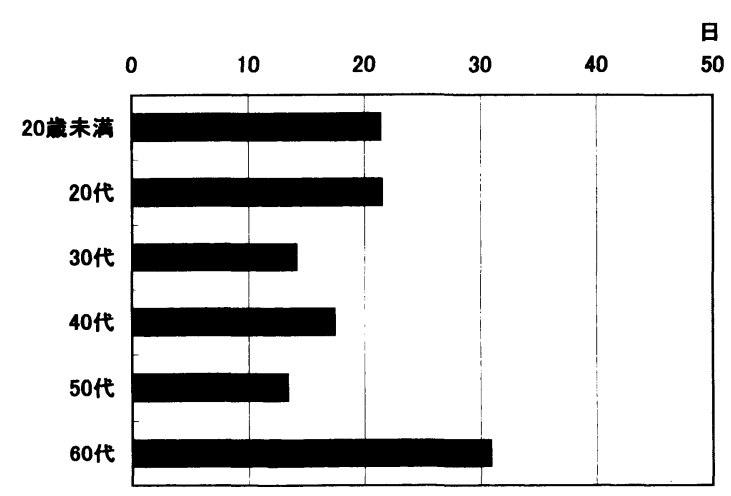

図 3 治療期間と年齢層の関係（Neb）

耳鼻科的処置の重要性を再検討する必要があると報告し ており，本邦におけるガイドラインの作成が重要である としている。

我々は, 急性副鼻腔炎の治療期間は, 䍜患期間, アレ ルギー性鼻炎の合併，年齢および Proetz, Neb および Schmidt のような耳鼻科的処置の順で影響を受けている と報告しだ。

小児急性副鼻腔炎治療において, Schmidtが最も有効 な治療法であるという報告がある5”。そして，リンデロ

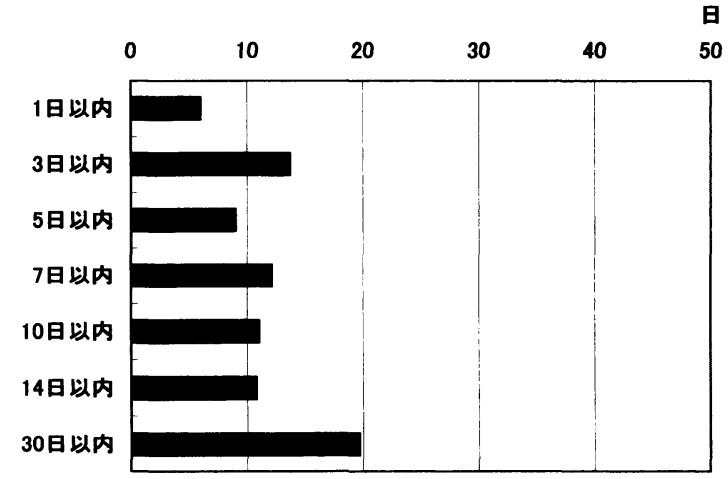

図 4 治療期間と罹患期間の関係（Schmidt） ン $\mathrm{A}$ 液 ${ }^{\circledR}$ のような抗生剂+ステロイド液での Proetzが 最も有効性が高いという報告もある4”。

ネブライザーを行う前に中鼻道を処置により大きく解 放し，清掃することが，その効果をより高くすることも 報告されている5-11)。抗生剤のネブライザーが有効であ るという報告は多いが, 耳鼻科的処置の有効性の報告は 数少ない。

図 5 から，20歳代以下および60歳代では, Schmidt が 有用な治療法と考える。しかし, 20歳以下, 特に10歳以 
表 3 多変量解析結果 (Schmidt)

\begin{tabular}{|c|c|c|c|c|}
\hline & & カテゴリー数量 & 度数 & 範囲 \\
\hline \multirow{7}{*}{ 罹患期間 } & 1 日以内 & -5.45345 & 15 & 13.030 \\
\hline & 3 日以内 & -0.13068 & 15 & 4 \\
\hline & 5 日以内 & -3.71529 & 7 & \\
\hline & 7 日以内 & -0.50903 & 21 & \\
\hline & 10日以内 & -1.80324 & 9 & \\
\hline & 14日以内 & -3.10208 & 17 & \\
\hline & 30日以内 & 7.57692 & 25 & \\
\hline \multirow[t]{7}{*}{ 年齢層 } & 20歳末満 & -4.48364 & 9 & 11.758 \\
\hline & 20歳代 & 2.07849 & 33 & 1 \\
\hline & 30歳代 & -0.50154 & 27 & \\
\hline & 40歳代 & -0.94467 & 18 & \\
\hline & 50歳代 & -5.15344 & 11 & \\
\hline & 60歳代 & 4.32877 & 6 & \\
\hline & 70歳代 & 6.60466 & 5 & \\
\hline \multirow[t]{5}{*}{ 抗生剂 } & セフェム & -1.98830 & 37 & 6.9950 \\
\hline & ペニシリン & 1.19790 & 4 & \\
\hline & マクロライド & 5.00674 & 16 & \\
\hline & 合成抗菌剂 & -0.70701 & 24 & \\
\hline & 抗生剂なし & 0.20129 & 28 & \\
\hline \multirow[t]{2}{*}{ アレルギー性鼻炎合併 } & $(+)$ & 1.42541 & 9 & 1.5537 \\
\hline & $(-)$ & -0.12829 & 100 & \\
\hline
\end{tabular}

\begin{tabular}{|c|c|}
\hline 重相関係数 & 決定係数 \\
\hline 0.5455 & 0.2975 \\
\hline
\end{tabular}

Schmidt

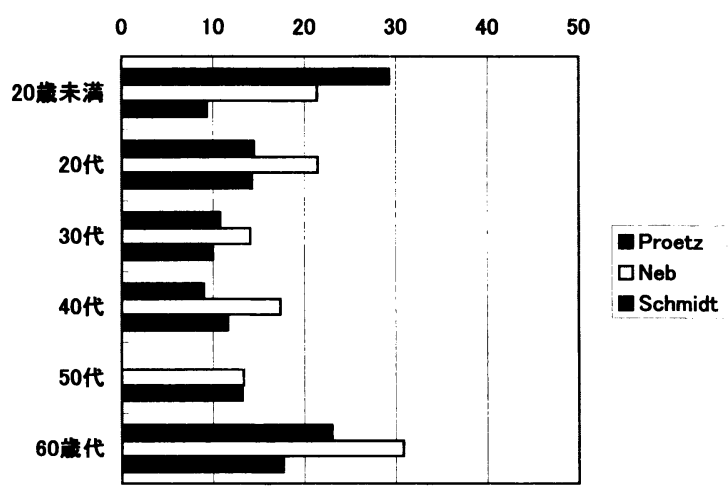

図 5 各年齢層別，耳鼻科的処置別平均治療期間

下の症例では，症例の協力が得られにくい場合には Schmidt および Proetzではなく, Neb がより有用な場 合もある。

また，30歳代ではどの治療法でもその有用性に大きな 差は認めない。症例との話し合いで治療法を選択してよ いと考える。

また，40歳代では，Proetz が有用な治療法と考える。

$$
\text { V. まとめ }
$$

急性副鼻腔炎治療における耳鼻科的処置の有用性につ
いて検討した。

1）プレッツ置換法は40歳代の症例で有用な治療法で ある。

2） ネブライザー療法は30歳代の症例で有用な治療法 である。

3）上顎洞穿刺洗浄法は，罹患期間が15日を越えた症 例では有用とはいえない。

4）上顎洞穿刺洗浄法は, 罹患期間の短い症例で有用 な治療法である。

\section{参考文献}

$1)$ Takano S, Tanaka N, Kurihara H, et al : Retrospective Study of Otolaryngological Treatment for Acute Sinusitis. Jpn J Rhinol 42(2) : 125-129, 2003.

2 ) Antimicrobial Treatment Guidelines for acute bacterial rhinosinusitis. Sinus and Allergy Health Partnership. Otolaryngol Head and Neck Surg 123:432,2000

3 ) Pichichero $M$ : Short Courses of Antibiotics in Acute Otitis Media and Sinusitis Infections. J of International Medical Reseach 28 (1) : 25-36, 2000. 
4) 杉田麟也, 小松信行, 出口浩一, 他 : 小监副鼻腔炎 からの耐性肺炎球菌検出状況と Clavlanic Acid/ Amoxicillin 投与症例の検討. The Jap J of Antibiotics 52 (10) : 613-627, 1999.

5 ) Temple ME, Nahata MC : Pharmacotherapy of acute sinusitis in children. Am J of Health-Syst Pharm 57 (7) : 663-668, 2000.

6 ）高野信也：上顎洞穿刺洗浄法及び Proetz 氏置換法 の効果. 小览耳鼻咽喉科 $17(1): 36-38,1996$.

7 ）木村有一, 山田武千代, 藤枝重治, 他 : ネブライザ 一療法における副鼻腔自然孔開放処置（中鼻道処 置）の有効性. 耳展 $45: 26-30,2002$.

8 ）山田武千代, 斉藤 等, 藤枝重治, 他：耳鼻咽喉科 的処置一鼻副鼻腔炎における中鼻道処置の有効 性一。耳鼻臨床 95(2)：153-157，2002.
9 ）竹野幸夫, 夜陣紘治, 小村 良：副鼻腔陰影に及ほ すエアロゾル療法の効果. 耳展 $45 ： 21-24,2002$.

10）荘司邦夫，間島雄一：耳鼻咽喉科処置一花ネブライ ザー療法の有用性とその評価一。耳鼻臨床 95(1)： 31-37, 2002.

11）寺田哲也, 北川美和, 中村雅宏, 他：副鼻腔自然口 開大処置の重要性一中鼻道開大処置の有用性につい ての臨床的検討一. 日鼻誌 41(2) : 132-136, 2002.

(2003年10月 22 日受稿, 2004 年 6 月 24 日受理) 別刷請求先 : 高野 信也 干 222-0036 横浜市港北区小机町 3211 横浜労災病院耳鼻咽喉科

Tel : 045-474-8111 Fax : 045-474-8323 